ISAHP 2003, Bali, Indonesia, August 7-9, 2003

\title{
THE BEST POLICY FOR EUROPEAN UNION \& TURKEY RELATIONSHIP: ANALYTIC NETWORK PROCESS APPROACH
}

\author{
Ebru P. Alikalfa \\ eayas@ogu.edu.tr \\ Mujgan S. Ozdemir \\ mujgano@ogu.edu.tr \\ Industrial Engineering Department \\ Osmangazi University \\ Bademlik Campus, 26030 Eskisehir-Turkey
}

Keywords: European Union, Turkey, Analytic Network Process, complex decision making

\section{Introduction}

This study aims at determining the best policy for the relationship between the European Union and Turkey with the Analytic Network Process (ANP). The analysis focuses on the following questions :

- What will Turkey contribute to the European Union?

- What will be the enhancement that Turkey will bring to the European Union?

- What will be the advantages that Turkey will derive, being part of the European Union?

ANP models are constructed for both the European Union and Turkey sides. Alternatives are determined as: Membership of Turkey in a short time, Non-membership of Turkey and giving Turkey a private status by considering the benefits of both sides. The alternatives were selected to be acceptable to both parties.

\section{Description of the European Union Model}

In EU model, 39 criteria were prioritized by pairwise comparisons and 12 of them with the highest priority constitute the majority and selected to have subnets of actors and their influences developed. These are, Young and Dynamic Population, Geostrategic Importance, Connecting Islam and West, Finance from Community's Budget and Regional Funds, Free Mobility of Labor, Population Size, Geographic Criteria about Europe's Boundaries, Access to Potential Markets, "Achieving Grande Europe", Unstable Economy and Worries about Turkey's Credentials. Determining these criteria is also supposed to be helpful for EU and Turkey to show them the critical factors to consider while making their decisions.

\subsection{Results for EU Model}

After doing pairwise comparisons and entering judgments including all clusters and nodes, the priorities for the elements in each network are determined. Three types of formula are used to analyze the merits. First of all subtractive formula is used.This formula leads us through a pessimistic way and for EU side, Private Status alternative becomes the most important one. Membership alternative takes the second priority with this formula. Then, we used probabilistic additive formula with BOCR rating values to obtain the overall results for EU. Since the high cost and high risk alternatives have the highest priorities, using the formula one minus the value coming up from the subnet changes the highest priorities from most costly (risky) to least costly (risky) and adding is appropriate. The results are remarkable and they indicate that Membership and private status take the highest priority with overall priority of 0.409 , so both of them are acceptable and considerable. Non- Membership gets the second priority. Also, we used additive formula to analyze the previous situation. As the inverses of Costs and Risks are used in additive formula, Membership option takes the first priority and Non-membership takes the second priority. However, the value of the Non-membership alternative is close to that of Private Status as can be seen in Table 1. 
Table 2. Overall Results bB+oO-cC-rR, bB+oO+c(1-C)+r(1-R) and bB+oO+c(1/C)+r(1/R)

\begin{tabular}{|l|c|l|c|l|c|c|c|}
\hline Alternatives & $\begin{array}{l}\text { Benefits } \\
(\text { Norm. }) \\
(0.322)\end{array}$ & $\begin{array}{l}\text { Opportunities } \\
(\text { Norm. } \\
(0.156)\end{array}$ & $\begin{array}{l}\text { Costs } \\
(\text { Norm. }) \\
(0.365)\end{array}$ & $\begin{array}{l}\text { Risks } \\
(\text { Norm. }) \\
(0.157)\end{array}$ & $\begin{array}{l}\text { bB+oO- } \\
\text { cC-rR }\end{array}$ & $\begin{array}{l}\text { bB+oO+c(1- } \\
\text { C)+r(1-R) } \\
(\text { Norm. })\end{array}$ & $\begin{array}{l}\text { bB+oO+c(1/C)+r(1/R) } \\
(\text { Norm. })\end{array}$ \\
\hline \hline Membership & 0.125 & 0.230 & 0.070 & 0.062 & 0.04 & 0.409 & 0.735 \\
\hline $\begin{array}{l}\text { Non- } \\
\text { Membership }\end{array}$ & 0.130 & 0.104 & 0.477 & 0.260 & -0.156 & 0.181 & 0.134 \\
\hline Private status & 0.743 & 0.665 & 0.448 & 0.677 & 0.07 & 0.409 & 0.131 \\
\hline
\end{tabular}

\section{Description of the Turkey Model}

In Turkey model, 46 criteria were prioritized by pairwise comparisons and 11 of them with the highest priority were selected. These are, Finance from Community's budget and regional funds, Investments, Majority in parliament, Allocation of money to budget and regional funds, Compensation for minorities, Minorities, Borders, Straightened economy, Cultural and social union, Economic dependency, Future of EU. To economize the effort, we used these criteria to put decision networks under.

\subsection{Results for Turkey Model}

According to Turkey ANP model, subtractive formula results show us that Membership is the best option. The other alternatives take negative priority and less preferable.The results obtained by using the probabilistic additive formula show that Membership takes the highest priority. Also, Private Status is the second in preference and Non-membership takes the last priority. After synthesizing with the additive formula, results indicate the Membership alternative as the most appropriate option. On the other hand, Non-membership alternative takes the second priority and Private Status alternative takes the last priority.

Table 2. Overall Results bB+oO-cC-rR, bB+oO+c(1-C)+r(1-R) and bB+oO+c(1/C)+r(1/R)

\begin{tabular}{|l|c|c|c|c|c|c|c|}
\hline Alternatives & $\begin{array}{c}\text { Benefits } \\
(\text { Norm.) } \\
(0.366)\end{array}$ & $\begin{array}{c}\text { Opportunities } \\
(\text { Norm. }) \\
(0.152)\end{array}$ & $\begin{array}{c}\text { Costs } \\
(\text { Norm. }) \\
(0.307)\end{array}$ & $\begin{array}{c}\text { Risks } \\
(\text { Norm. }) \\
(0.173)\end{array}$ & $\begin{array}{l}\text { bB+oO- } \\
\text { cC-rR }\end{array}$ & $\begin{array}{c}\text { bB+oO+c(1- } \\
\text { C)+r(1-R) } \\
(\text { Norm. })\end{array}$ & $\begin{array}{c}\mathrm{bB}+\mathrm{oO}+\mathrm{c}(1 / \mathrm{C})+\mathrm{r}(1 / \mathrm{R}) \\
(\mathrm{Norm})\end{array}$ \\
\hline \hline Membership & 0.527 & 0.512 & 0.135 & 0.123 & 0.207 & 0.557 & 0.575 \\
\hline $\begin{array}{l}\text { Non- } \\
\text { Membership }\end{array}$ & 0.077 & 0.080 & 0.220 & 0.396 & -0.095 & 0.194 & 0.272 \\
\hline Private status & 0.395 & 0.407 & 0.643 & 0.479 & -0.073 & 0.248 & 0.152 \\
\hline
\end{tabular}

\section{Discussion and Interpretation of Results}

To determine the best policy for EU and Turkey relationship two ANP models are constructed. Three different formulas are used as subtractive, probabilistic additive and additive to synthesize BOCR.As alternatives are evaluated according to BOCR merits for EU, it can be seen that Private Status alternative comes into agenda on behalf of Benefits, Oppurtunities. Membership alternative is the most preferable one when we consider Costs and Risks in EU model. In the EU model Private Status alternative becomes a matter of primary importance with subtractive and probabilistic additive formulas. Membership alternative seems more suggestable according to additive formula. On the other side in Turkey model, Membership is chosen mostly under Benefits, Oppurtunities, Costs and Risks. Also Membership alternative gets the best overall value under both formulas and becomes the best option. Interpreting the results independently allowed us to analyze the sensitivity of both sides. It is risky to combine the results of two models by simply adding and subtracting BOCR values because Benefits or Opportunities for one side does not totally constitute Costs or Risks for the other. Further research will be concerned with conducting sensitivity analysis for the BOCR values of the two models and combining the results in a suitable way. 